\title{
Effects of prenatal cigarette smoke exposure on BDNF, PACAP, microglia and gliosis expression in the young male mouse brainstem.
}

\section{Rita Machaalani ${ }^{a}$, Melisande Thawley ${ }^{\text {a }}$, Jessica Huang ${ }^{\text {a }}$, Hui Chen ${ }^{\text {b }}$}

aSIDS and Sleep Apnea Laboratory, Sydney Medical School (Central), Medical Foundation Building, K25; University of Sydney, NSW 2006, Australia, ${ }^{b}$ School of Life Sciences, Faculty of Science, University of Technology Sydney, Broadway, NSW 2007 Australia

\section{Address for Correspondence:}

Rita Machaalani

Department of Medicine

Room G77, Medical Foundation Building, K25

University of Sydney

NSW 2006, Australia

Tel: +61 290363482

Email: rita.machaalani@sydney.edu.au

Total Number of Pages: 20

Number of Figures: 2

Number of Tables: 2

\section{Highlights:}

-Prenatal cigarette smoke exposure (SE) affected BDNF \& TrkB in the XII of P20 mice.

-Only PAC1 expression was increased by SE, with no effect on PACAP.

-There were no changes in GFAP or IBA-1 expression after SE in the nuclei studied.

- The XII \& NTS were the nuclei predominantly affected in this study. 


\begin{abstract}
:
Cigarette smoke exposure during pregnancy into infancy affects brain growth and development in both short and long term (into adulthood). Using a mouse model of pre- into post- natal cigarette smoke exposure (SE), we aimed to determine the effects on brain derived neurotrophic factor (BDNF) and its receptor TrkB, neuropeptide pituitary adenylate cyclase activating polypeptide (PACAP) and its receptor PAC1, and astrocyte (GFAP) and microglia (Iba-1) immunohistochemical expression, in seven nuclei of the medulla and the facial (FAC) nucleus of the pons. Male pups of dams exposed to two cigarettes (nicotine $\leq 1.2 \mathrm{mg}, \mathrm{CO}$ $\leq 15 \mathrm{mg})$ twice daily for six weeks prior to mating, during gestation and lactation $(n=5 ; S E)$, were compared to pups exposed to air under the same condition ( $n=5$; SHAM) at postnatal day 20. Expression changes were only evident for BDNF, TrkB and PAC1 and included decreased BDNF in the hypoglossal (XII) nucleus and nucleus of the solitary tract (NTS), increased TrkB in XII but decreased TrkB in the FAC, and increased PAC1 in 4 nuclei of the medulla including the NTS. These results suggest that the effect of SE on the brainstem are region and marker selective, affecting regions of respiratory control (XII and NTS), and restricted to the BDNF system and PAC1, with no effect on activation states of astrocytes or microglia.
\end{abstract}

Keywords: Iba-1, GFAP, nicotine, PAC1, Sudden Infant Death Syndrome (SIDS), TrKB.

\footnotetext{
Abbreviations:

BDNF, brain derived neurotrophic factor; Cun, cuneate nucleus; DMNV, dorsal motor nucleus of the vagus; FAC, Facial nucleus; GFAP, glial fibrillary acidic protein; Iba-1, ionized calcium-binding adaptor molecule 1; IHC, immunohistochemistry; ION, inferior olivary nucleus; LRt, Lateral Reticular Nucleus; NSTT, nucleus of the spinal trigeminal tract; NTS, nucleus of solitary tract; PACAP, Pituitary Adenylate Cyclase Activating Polypeptide; SIDS, sudden infant death syndrome; XII, hypoglossal nucleus
} 


\section{Introduction}

Cigarette smoking during pregnancy is associated with a number of adverse prenatal conditions such as low birth weight (Bernstein et al, 2005), still birth (Wisborg et al, 2001) and preterm delivery (Fantuzzi et al, 2008), as well as postnatal adversities including altered brain growth and development (reviewed Chang et al., 2014), and increased physiological dysfunction related to the cardiovascular, respiratory, sleep and arousal systems (reviewed by Vivekanandarajah et al., 2018), including an incidence of asthma and wheezing (Gilliland et al 2001), impaired pulmonary function (Di Franza et al, 2004), altered cardiac responses during hypoxic conditions (Sovik et al., 2001) and increased risk for Sudden Infant Syndrome (SIDS) (Hoffman et al, 1988).

Data from our laboratory suggests that these postnatal adversities are in part, due to abnormal regulation of the nicotinic acetylcholine receptors (nAChRs) in brainstem centres, as found in infants who died of SIDS with a known history of cigarette smoke exposure (Machaalani et al., 2011, Aisha et al., 2019), and in infant mice from mothers exposed to cigarette smoke (Vivekanandarajah et al., 2016). In both cohorts, the final cellular outcome was found to be increased cell death (apoptosis) (infants: Machaalani et al., 2007, Machaalani and Waters 2008, mouse model: Vivekanandarajah et al., 2016). Subsequent studies from our laboratory to determine the pathways of cigarette smoke exposure induced apoptosis indicated a role of abnormal expression of the growth factor, brain derived neurotrophic factor (BDNF) (Tang et al., 2012), and of the neuropeptide pituitary adenylate cyclase activating polypeptide (PACAP) (Huang et al., 2017a), with both being specific to the hypoglossal nucleus of the medulla.

A likely mechanism leading from the activation of the nAChRs to abnormal BDNF and PACAP expression, and to the final step of apoptosis of the cell, is neuroinflammation and oxidative stress. Astrocytes and microglia, play an important role in neuroinflammation (reviewed Liberman et al., 2018). Glial fibrillary acidic protein (GFAP) is a marker used to identify activated astrocytes, while ionized calcium-binding adaptor molecule 1 (Iba-1) is used to identify activated microglia. To date, no study has looked at the activation of these cell types in the brainstem of humans or animal models of pre-into -postnatal cigarette smoke exposure on the developing offspring. The only studies available are those using pure nicotine administration (pre or post-natally) and investigating the expression in higher cortical brain regions in adulthood (Summarized Table 1). 
Using a mouse model of pre-into postnatal maternal cigarette smoke exposure (SE), this study aimed to determine the effects on the expression of BDNF, its tyrosine kinase receptor (TrkB), PACAP and its receptor polypeptide type 1 receptor (PAC1), GFAP and Iba-1, in the brainstem medulla and facial nucleus of the pons of the male off-spring at postnatal day 20 . Our hypothesis was that the BDNF and PACAP would be decreased in nuclei of respiratory regulation, and this would be associated with an increase in astrocytes (GFAP) and microglia (Iba-1).

\section{Methods}

\subsection{Maternal cigarette smoke exposure}

The exposure regime was as we have detailed previously (Vivekanandarajah et al.,2016, Chan et al., 2016a, b). The protocol was performed according to the Australian National Health \& Medical Research Council Guide for the Care and Use of Laboratory Animals and was approved by the Animal Care and Ethics Committee at the University of Technology Sydney (ACEC\#2011-313A).

Briefly, virgin Balb/c mice (6 weeks) were obtained from Animal Resources Center (Perth, Australia), and housed at $20 \pm 2^{\circ} \mathrm{C}$ being maintained on a 12-h light, 12-h dark cycle (lights on at 06:00 h) with ad libitum access to standard laboratory chow and water. The mice were randomly assigned to sham (SHAM) or cigarette smoke exposure (SE) groups and had this delivered in a perspex chamber of $15 \mathrm{~L}(40 \times 27 \times 20 \mathrm{~cm})$ at room temperature. The SE group were exposed to two standard regular cigarettes (Winfield Red, nicotine $\leq 1.2 \mathrm{mg}, \mathrm{CO} \leq 15$ mg, Philip Morris, VIC, Australia) twice daily (10:00h and 15:00h) for six weeks prior to mating, during gestation and lactation, and this was delivered for 15 minutes, with a 5-minute interval between the two cigarettes. The SHAM mice were placed in a separate identical perspex chamber to avoid any contamination and air exposure delivered under the same condition. All females were mated with non-cigarette smoke exposed 8 week old male Balb/c mice from the same source.

\subsection{Tissue Collection}

At postnatal day 20 (P20; normal weaning age), male offspring were anesthetized with 4\% isofluorane and then sacrificed by decapitation. We focused on male mice as it has been shown that in this model, male offspring are more vulnerable to the impact of maternal SE 
than females (Chan et al., 2016a). The brain stem with cerebellum intact, was collected and fixed with $10 \%$ formalin, rinsed in $70 \%$ ethanol and processed to paraffin embedding. Tissue blocks were sectioned at $4 \mu \mathrm{m}$ by a rotary microtome (Shandon Finesse 325, Thermo Fisher Scientific Inc, Massachusetts, USA), mounted onto silanized slides, dried overnight at $45^{\circ} \mathrm{C}$ and stored at room temperature in a dust-free environment for immunohistochemical staining.

\subsection{Immunohistochemistry (IHC)}

Sections from all cases were stained within the same experimental run for each respective antibody to avoid day-to-day variation. Duplicate staining was performed on $20 \%$ of cases to verify the reproducibility of results. IHC method is standard for our laboratory and is detailed in Tang et al., 2012 and Huang et al., 2017a. The antibodies used are summarized in Table 2.

Briefly, all steps were performed at room temperature unless otherwise noted. Tissue sections were deparaffinised to distilled $\mathrm{H}_{2} \mathrm{O}$ and heat-induced epitope retrieval was applied by microwaving on 'high' (Homemaker; EM925ENV; 900W) in 10\% TRIS-EDTA antigen retrieval buffer (1 mM EDTA, $1 \mathrm{mM}$ sodium citrate, $2 \mathrm{mM}$ Tris, $\mathrm{pH} 9.0$ ) for $14 \mathrm{~min}$. After cooling and rinsing with distilled water, sections were washed with phosphate buffered saline (PBS), a hydrophobic barrier was drawn surrounding the sections and endogenous hydrogen peroxidase quenched in 50\% PBS, 50\% methanol and 3\% $\mathrm{H}_{2} \mathrm{O}_{2}$ for $15 \mathrm{~min}$ at room temperature, followed by two washes in PBS. Sections were blocked by $10 \%$ normal horse serum (NHS) in PBS for 30 min then incubated with primary antibodies (Table 2) overnight at room temperature. Negative controls were incubated with 1\% NHS only. After two PBS washes on day 2 , sections were incubated with biotinylated anti-rabbit secondary antibody made in horse (BA-1100, Vector Laboratories Inc., California, USA) for 1 hour and then in avidin-biotin complex (ABC) (VEPH4000, Vector Laboratories Inc., California, USA) for 1 hour. The sections were color-labelled with 3,3'-diaminobenzidine (DAB) (VESK4100, Vector Laboratories Inc., California, USA), followed by counterstaining with Harris's Haematoxylin, dehydration through graded ethanol to xylene, mounted with Di-n-butyl Phthalate in Xylene (DPX) and coverslipped.

\subsection{Quantitative Analysis}

Nuclei of interest in the caudal medulla and pons were identified and imaged with reference to The Mouse Brain Atlas (Fig. 94 \& 79-83 respectively; Paxinos \& Franklin, 2004). Seven nuclei at the caudal medulla [hypoglossal nucleus (XII), dorsal motor nucleus of the vagus (DMNV), 
nucleus of the solitary tract (NTS), cuneate nucleus (Cun), nucleus of the spinal trigeminal tract (NSTT), lateral reticular nucleus (LRt), and inferior olivary nucleus (ION)], and the facial nucleus (FAC) of the pons were studied.

For BDNF, TrkB, PACAP and PAC1, staining was imaged with a DCF 400 (Leica Microsystems Ltd. Heerbrugg, Switzerland) mounted on a Leica DM6000 Nikon Upright at 20x magnification and captured using the Leica application suite software (LAS V3.8, Leica Microsystems Ltd., Heerbrugg, Switzerland). Quantification was of neurons only since these were the predominant cell type stained for these markers (Figure 1). Neurons in each nucleus were quantified blinded to the study group, using the cell counter function in ImageJ software (National Institutes of Health, USA). Positively and negatively stained neurons in each nucleus were counted manually and the percent of positive neurons for each region was calculated. Neurons with brown coloured somata were deemed positive, while neurons with lighter staining similar to the connective tissue staining colour, or blue due to the haematoxylin counter stain, were deemed negative.

For GFAP, staining was imaged at 10x magnification and analysis was of the percentage of total area of positive staining in each nucleus via the color, deconvolution, threshold, and measure function using ImageJ software. For Iba-1, staining was assessed at 40x magnification and was a count of the number of positive cells per region analysed. Values were then exported into excel for calculation.

\subsection{Statistical Analysis}

The anthropometry results and the immunohistochemistry data are presented as the mean \pm standard error of the mean (SEM). Statistical analysis was performed using one-way analysis of variance (ANOVA) (IBM SPSS Statistics 24 for Windows. IBM Corp., USA) comparing offspring from the maternal SE group $(n=5)$ to the SHAM controls $(n=5)$; offspring from the SE group were from 4 different litters, while those from the SHAM group were from 2 different litters. No adjustment for this was made statistically. A $p$-value $<0.05$ was considered significant. 


\section{Results}

\subsection{Mouse characteristics}

As reported previously (Vivekanandarajah et al., 2016), SE mice had decreased body (9.96 \pm 0.44 vs $11.44 \pm 0.28$ grams, $p=0.01)$ and brain $(0.27 \pm 0.00$ vs $0.29 \pm 0.00$ grams, $p=0.003)$ weight when compared to Sham. These are common features of offspring from smoking mothers (reviewed in Abbott and Winzer-Sehan, 2012). Level of smoke exposure was determined via serum cotinine which was found to be significantly higher in SE pups (8.93 \pm 0.87 vs $2.52 \pm 0.35 \mathrm{ng} / \mathrm{mL} ; \mathrm{p}<0.001)$. This level is within the range reported in human infants of smoking mothers (5 to $30 \mathrm{ng} / \mathrm{ml}$; Luck and Nau 1985) with levels $<5 \mathrm{ng} / \mathrm{ml}$ indicative of background noise (Luck and Nau 1985, Benowitz et al., 2009).

\section{2. $B D N F, T r k B, P A C A P$ and $P A C 1$ expression}

All nuclei studied had some expression for all these markers. Based on the SHAM group, BDNF and TrkB expression ranged from $20-40 \%$ amongst the nuclei while for PACAP and PAC1, this ranged from 40-80\% (Figure 2).

Comparing SE to SHAM mice, for BDNF, there was a decrease in the XII $(p=0.03)$ and NTS $(\mathrm{p}=0.04)$, and an increase in the ION ( $\mathrm{p}=0.05)$ (Figure 2). For TrkB, expression was increased in the XII $(\mathrm{p}=0.02)$ and decreased in the FAC $(\mathrm{p}=0.005)$. For PACAP, no changes were evident, whereas for PAC1, expression was increased in the NTS ( $p=0.009)$, Cun, NSTT and ION $(\mathrm{p}<0.05)$ (Figure 2).

\subsection{GFAP and Iba-1 expression}

GFAP staining (Figure 1) was seen in all mice and in all nuclei studied and ranged from 0.51.5 percent area of expression (Figure 2). For Iba-1, expression was low and not observed in all mice, with 3 SHAM and 2 SE mice showing some expression in the regions studied.

Comparing SE to SHAM mice, there was no difference in expression levels for either GFAP or Iba-1 (Figure 2). 


\section{Discussion}

The main findings of this study, which is the first to be conducted in the brainstem at early post-natal age, is that pre-into post-natal cigarette smoke exposure only affected BDNF, TrkB and PAC1 expression in select nuclei of the brainstem including the XII and NTS, both of which play an important role in respiratory control.

\subsection{Expression in the normal developing mouse brainstem}

This study is unique in that it is the first to report the protein IHC expression of all these markers simultaneously in the mouse brainstem. Regarding BDNF and TrkB expression, the overall average levels were $30 \%$ in the mouse medulla. This is lower than what we previously found in the human infant (averaged 50\%; Tang et al., 2010) and young piglet (averaged 60\%; Tang et al., 2008). The most likely explanation for this is that, at P20, these mice were past the greatest developmental brain growth period, which in rats regarding highest BDNF expression in the brainstem, occurs at P7-10, while for TrkB occurs at P10-11 (Lui and Wong Riley, 2013).

For PACAP, the average percentage expression in the mouse was $70 \%$ which is similar to the piglet (Huang et al., 2017b) and lower than the human (90\%; Huang et al., 2017a) when excluding the NTS as it had very low expression (Huang et al., 2017a,b). For PAC1, the average was $40 \%$ in the mouse, similar to the $30 \%$ average in human (Huang et al., 2017a), and $50 \%$ in piglets (Huang et al., 2017b).

The higher expression of PACAP/PAC1 compared to BDNF/TrkB found in our mice, consistent with human and piglet studies detailed above, suggests that during development, neurons of most brainstem medullary nuclei require more PACAP than BDNF for growth and development. This is further supported by work in the rat brainstem medulla where the optical density for PACAP averaged 0.4 (Lui and Wong Riley 2019), but for BDNF/TrkB it averaged 0.3 (Lui and Wong Riley 2013), representing a 25\% difference.

Baseline levels of GFAP were lowest in the motor nuclei of the XII and FAC of the P20 mice, and is similar to the low expression reported in these nuclei in mice aged 8 months (Kadoyama et al., 2007). Iba-1 was not seen in most of the mice in this study. For the mice with some Iba1, expression, this was low in all the nuclei studied yet was highest in the XII and FAC. Similarly, higher Iba-1 than GFAP in these nuclei was reported in mice aged 8 months (Kadoyama et al., 2007). Combined, this suggests that the astrocyte population in these nuclei 
is smaller than the microglia population through to adulthood.

\subsection{Effects of pre- into post-natal SE on expression levels}

We recently reviewed the effects of SE and nicotine on BDNF and TrkB expression and showed that all previous studies were of cortical regions, the striatum, or the hippocampus (Machaalani and Hui 2018). No other studies have looked at SE on PACAP and PAC1 with the exception of our group where we report these within the brainstem of piglets exposed to nicotine postnatally (BDNF/TrkB- Tang et al., 2008; PACAP/PAC1 - Huang et al., 2017b) as well as human infants exposed to SE (BDNF/TrkB- Tang et al., 2012; PACAP/PAC1 - Huang et al., 2017a).

Our finding that the XII had altered BDNF and TrkB expression in the SE mice, is consistent with our finding in human infants (Tang et al., 2012) and piglets exposed to postnatal nicotine alone (Tang et al., 2008), albeit the direction of change was the opposite. The combined decreased BDNF and increased TrkB in the XII of our mice suggests a coordinated action of agonist and receptor, where an increase in TrkB could be the adaptive cellular response to lower BDNF, and could be considered as a protective compensatory effect promoting neuroprotection by increasing receptor availability.

Finding PAC1 was increased in four nuclei within this study is surprising when considering we saw no change in its expression in infants exposed to cigarette smoke (Huang et al., 2017a) while in our piglets, nicotine decreased PAC1 in the DMNV only (Huang et al., 2017b). Furthermore, it is surprising that the changes were not associated with alteration in PACAP given the PAC1 receptor is relatively selective (1000x higher affinity) for PACAP than for vasoactive intestinal polypeptide (VIP) (Vaudry et al., 2000). Given the lack of any other studies that have looked at cigarette smoke or nicotine effects on PAC1, we can only hypothesize that the increase in PAC1 expression in our P20 mice could be via the MAP kinase pathway since it regulates PAC1 promoter activity, despite the absence of PACAP treatment effect on it (Jamen et al., 2002). This could subsequently lead to the activation of the downstream intracellular pathways via Gas coupling to adenylate cyclase leading to an increase in protein kinase A (PKA) (reviewed Dickson and Finlayson, 2009), or the PKC to release calcium (reviewed Farnham and Pilowski, 2010).

The combined increase in PAC1 and decrease in BDNF in the NTS, as well as increased PAC1 and increased BDNF in the ION are interesting suggesting that any abnormal physiologies related to these nuclei in relation to SE exposure, is due to abnormalities in both 
PAC1 and BDNF. Indeed, a relationship between PAC1 and BDNF has been reported and include: 1- decreased BDNF expression (but no change in TrkB) in PAC1 knockout mice (Zink et al., 2004), 2- BDNF treatment stimulated PAC1 promotor activity in cultured cerebellar cells (Jamen et al., 2002), and 3- a negative correlation between BDNF and PAC1 expression after antidepressant treatments (Reichenstein et al., 2008).

Based on the limited literature available for the effects of maternal SE and nicotine exposure on GFAP and Iba-1 expression (summarized table 1), the overall consensus is that prenatal cigarette smoke exposure has no real effect on GFAP or Iba-1 expression in the adult rodent brain, yet specific postnatal nicotine exposures increase the expression. Our study is consistent with the prenatal exposures having no effect (Chang et al., 2013, Zelikoff et al., 2018) and indicative that astrocytes and microglia levels are stable in the brainstem of mice at P20 after long term SE exposure, and that neuroinflammatory processes are not active.

\subsection{Nuclei affected and correlation with apoptosis and nicotine acetylcholine receptors (nAChRs)}

The three nuclei that were predominantly affected (that is, had a change in more than one marker) by the SE exposure in this study, were the XII, NTS and ION. Combining the data with that from our study of apoptotic and $\mathrm{nAChR}$ expression in these same mice (Vivekanandarajah et al., 2016), the following changes are present in these nuclei:

1- XII- decreased BDNF, increased TrkB, increased active caspase-3, and an increase in the nAChR subunits $\alpha 3, \alpha 4, \alpha 7$, and $\alpha 9$,

2- NTS- decreased BDNF, increased PAC1, no change in apoptosis, an increase in the $\alpha 3$ and $\alpha 5$ but decrease in $\alpha 4 \mathrm{nAChR}$ subunits,

3- ION- increased BDNF, increased PAC1, decreased active caspase-3 and TUNEL, no change for the nAChR subunits.

Thus, for the XII and NTS, it can be concluded that the effects of maternal SE on BDNF and PAC1 are closely related to the interaction with several nAChR subunits. This is consistent with findings where PAC1 activated adenylate cyclase- (AC-) and phospholipase-C- (PLC) dependent transduction cascades (Margiotta and Pardi, 1995, Pardi and Margiotta, 1999) resulting in signaling that regulated both heteromeric $n A C h R s$ (containing $\alpha 3, \alpha 5, \beta 4, \pm \beta 2$ subunits) and homomeric $\alpha 7 \mathrm{nAChRs,} \mathrm{and} \mathrm{mobilized} \mathrm{intracellular} \mathrm{calcium} \mathrm{(Margiotta} \mathrm{and}$ Pardi, 1995, Pardi and Margiotta, 1999). The increase in cellular calcium influx could 
subsequently be toxic leading to cell death (apoptosis). These changes would ultimately lead to altered physiologies which for the XII would include abnormal regulation of the upper airway muscles including the genioglossus (Boone and Aldesm 1984), and for the NTS would include abnormal cardiorespiratory control (reviewed Dampney 1994). For the ION, which is involved in the coordination of movement and balance (Bengtsson and Hesslow, 2006), the alteration in BDNF and PAC1 are independent of the nAChRs which suggests that these are due to other (non-nicotine) toxic components of cigarette smoke of which there are over 4800 (Green and Rodgman 1996).

\section{Conclusion}

The results of this study show for the first time that at P20, pre-into post-natal cigarette smoke exposure only affected BDNF, TrkB and PAC1 expression in select nuclei of the brainstem in mice, including the XII and NTS, both of which play an important role in respiratory control. The lack of any change in GFAP and Iba-1 expression suggests neuroinflammatory pathways may not have been activated or have reached stable conditions due to the long-term exposure. These results provide further evidence of the lasting adverse effects of prenatal cigarette smoke exposure on the proteins important for growth and development of the brain especially to regions of specific respiratory control.

\section{Acknowledgements}

The animal exposure and brain collection were performed by Dr Yik (Jeremy) Lung Chan at the University of Technology Sydney. A Summer Vacation Scholarship by the Sydney Medical School, University of Sydney supported author MT who undertook the staining and quantification of the BDNF and TrkB of this study. The authors acknowledge the facilities, scientific and technical assistance, of the Australian Microscopy and Microanalysis Research Facility at the Australian Centre of Microscopy and Microanalysis, University of Sydney.

\section{Conflicts of interests}

The authors have no conflicts of interest. 


\section{Figure Legends}

Figure 1: Representative images of the immunohistochemical staining for the markers in the hypoglossal (XII) and DMNV (A-D) of the same mouse, and Cun (E,F) nucleus. Positive staining for the marker is indicated by brown colour. Scale bar represents $100 \mu \mathrm{m}$ for A-D, and $50 \mu \mathrm{m}$ for E,F.

Figure 2: Comparison of the expression of the markers between SHAM (white bars, $n=5$ ) and SE (black bars, $n=5$ ) mice in 7 nuclei of the caudal medulla and the facial (FAC) nucleus of the pons. Results are presented as mean \pm SEM. ${ }^{*} \mathrm{p}<0.05,{ }^{* *} \mathrm{p}<0.01$. 
Table 1: Summary of studies looking at GFAP and Iba-1 after cigarette or nicotine exposure.

\begin{tabular}{|c|c|c|c|c|c|}
\hline $\begin{array}{l}\text { Exposure } \\
\text { Model }\end{array}$ & $\begin{array}{c}\text { Species, Sex \& } \\
\text { Developmenta } \\
\text { l age }\end{array}$ & $\begin{array}{l}\text { Brain } \\
\text { region(s) }\end{array}$ & $\begin{array}{l}\text { Microglia } \\
\text { and } \\
\text { Astrocyte } \\
\text { marker } \\
\end{array}$ & Results & $\begin{array}{c}\text { Reference } \\
\text { s }\end{array}$ \\
\hline \multicolumn{6}{|c|}{ Prenatal exposures } \\
\hline $\begin{array}{l}\text { Prenatal s.c. } \\
\text { Minipump } \\
\text { nicotine } \\
(3.3 \mathrm{mg} / \mathrm{kg} / \mathrm{day} \\
)\end{array}$ & $\begin{array}{l}\text { P30 and P60 } \\
\text { male \& } \\
\text { female rats }\end{array}$ & $\begin{array}{l}\text { cortex, } \\
\text { hippocampus, } \\
\text { thalamus and } \\
\text { cerebellum }\end{array}$ & GFAP & $\begin{array}{l}\uparrow \text { GFAP in CA1 } \\
\text { hippocampus } \\
\text { and cerebellum } \\
\text { associated with } \\
\uparrow \text { cell death }\end{array}$ & $\begin{array}{l}\text { Abdel- } \\
\text { Rahman } \\
2005\end{array}$ \\
\hline $\begin{array}{l}\text { Prenatal s.c. } \\
\text { osmotic } \\
\text { Minipump } \\
\text { nicotine } \\
(1.5 \mathrm{mg} / \mathrm{kg} / \text { day } \\
)\end{array}$ & P15 male rats & hypothalamus & $\begin{array}{l}\text { Iba-1, } \\
\text { GFAP }\end{array}$ & No changes. & $\begin{array}{l}\text { Chang et } \\
\text { al., } 2013\end{array}$ \\
\hline $\begin{array}{c}\text { Pre-into } \\
\text { postnatal e- } \\
\text { cigarette (with } \\
\text { vs without } \\
\text { nicotine) } \\
\end{array}$ & $\begin{array}{l}\mathrm{P} 20 \text { mice }(3 \mathrm{~F}, \\
3 \mathrm{M})\end{array}$ & $\begin{array}{l}\text { Hippocampus } \\
\text { and frontal } \\
\text { cortex }\end{array}$ & $\begin{array}{l}\text { Iba-1, } \\
\text { GFAP }\end{array}$ & $\begin{array}{c}\uparrow \text { Iba-1 in CA1 } \\
\text { of non-nicotine } \\
\text { e-cigarette. No } \\
\text { change for } \\
\text { GFAP. }\end{array}$ & $\begin{array}{c}\text { Zelikoff et } \\
\text { al., } 2017\end{array}$ \\
\hline \multicolumn{6}{|c|}{ Postnatal exposures } \\
\hline $\begin{array}{c}\text { Chronic } \\
\text { nicotine } \\
\text { exposure [i.p } \\
\text { injection of } \\
1 \mathrm{mg} / \mathrm{kg}, 5 \\
\text { times a day, } 4 \\
\text { weeks] }\end{array}$ & P30 male rats & $\begin{array}{l}\text { Cerebral } \\
\text { cortices }\end{array}$ & $\begin{array}{l}\text { anti-OX-6 } \\
\text { (specific for } \\
\text { major } \\
\text { histocompat } \\
\text { ibility } \\
\text { complex } \\
\text { class II) } \\
\text { for } \\
\text { microglia }\end{array}$ & $\begin{array}{c}\uparrow \text { number of } \\
\text { microglia }\end{array}$ & $\begin{array}{c}\text { Park et al., } \\
2007\end{array}$ \\
\hline $\begin{array}{c}\text { (NNK) } \\
\text { tobacco- } \\
\text { specific } \\
\text { procarcinogen } \\
\text { injections for } 4 \\
\text { or } 12 \text { days } \\
\end{array}$ & $\begin{array}{l}\text { 6week adult } \\
\text { male \& } \\
\text { female mice }\end{array}$ & $\begin{array}{l}\text { Cortex and } \\
\text { hippocampus }\end{array}$ & $\begin{array}{l}\text { Iba-1, } \\
\text { GFAP }\end{array}$ & $\uparrow$ for both & $\begin{array}{l}\text { Ghosh et } \\
\text { al., } 2009\end{array}$ \\
\hline $\begin{array}{c}4 \%(\mathrm{v} / \mathrm{v}, \\
\text { smoke/air) } \\
{[\mathrm{smoke}=11 \mathrm{mg}} \\
\text { Tar, } 0.8 \mathrm{mg} \\
\text { Nicotine], } \\
\text { 1hr/day for } 56 \\
\text { days }\end{array}$ & $\begin{array}{c}\mathrm{P} 35-40 \text { male } \\
\text { rats }\end{array}$ & $\begin{array}{l}\text { Cortex. } \\
\text { Western } \\
\text { blotting. }\end{array}$ & $\begin{array}{l}\text { Iba-1, } \\
\text { GFAP }\end{array}$ & No changes & $\begin{array}{l}\text { Lau et al., } \\
2012\end{array}$ \\
\hline $\begin{array}{c}\text { Maternal } \\
\text { osmotic } \\
\text { minipump } \\
\end{array}$ & P180 (adults) & hypothalamus & $\begin{array}{c}\text { Iba-1; } \\
\text { CX3CR1 } \\
\text { (microglia } \\
\end{array}$ & $\uparrow$ for all. & $\begin{array}{c}\text { Younes- } \\
\text { Rapozo et } \\
\text { al., } 2015 \\
\end{array}$ \\
\hline
\end{tabular}




\begin{tabular}{|c|c|c|c|c|c|}
\hline $\begin{array}{c}\text { during } \\
\text { lactation of } \\
\text { nicotine } \\
6 \mathrm{mg} / \mathrm{kg} / \text { day }\end{array}$ & & & $\begin{array}{l}\text { receptor); } \\
\text { GFAP }\end{array}$ & & \\
\hline $\begin{array}{l}10.4 \mathrm{mg} / \mathrm{kg} / \text { day } \\
\text { nicotine s.c. } \\
\text { osmotic pump }\end{array}$ & $\begin{array}{l}\text { Adult male } \\
\text { rats }\end{array}$ & $\begin{array}{l}\text { NSTT, } \\
\text { medullary } \\
\text { horn spinal } \\
\text { cord }\end{array}$ & $\begin{array}{l}\text { Iba-1; } \\
\text { GFAP }\end{array}$ & $\uparrow$ for both. & $\begin{array}{l}\text { Hawkins et } \\
\text { al., } 2015\end{array}$ \\
\hline $\begin{array}{c}\text { Moderate to } \\
\text { severe smokers }\end{array}$ & Human adults & Whole brain & $\begin{array}{l}\text { [11C]DAA1 } \\
106 \text { (a } \\
\text { ligand for } \\
\text { TSPO) via } \\
\text { PET scan } \\
\text { When } \\
\text { activated, } \\
\text { microglia } \\
\text { increase the } \\
\text { expression } \\
\text { of } \\
\text { translocator } \\
\text { protein } \\
\text { (TSPO). }\end{array}$ & $\downarrow$ binding & $\begin{array}{l}\text { Brody et } \\
\text { al., } 2017\end{array}$ \\
\hline
\end{tabular}


Table 2: Antibodies used for immunohistochemistry.

\begin{tabular}{|l|l|l|l|l|}
\hline Antibody target & $\begin{array}{l}\text { Company and } \\
\text { catalogue number }\end{array}$ & $\begin{array}{l}\text { Species } \\
\text { raised in }\end{array}$ & Dilution used & $\begin{array}{l}\text { Secondary } \\
\text { Antibody }\end{array}$ \\
\hline BDNF & $\begin{array}{l}\text { AB1779, } \\
\text { Millipore } \\
\text { Corporation, USA }\end{array}$ & $\begin{array}{l}\text { rabbit } \\
\text { polyclonal }\end{array}$ & $1: 1000$ & $1: 100$ \\
\hline TrkB & $\begin{array}{l}\text { AB5372, Chemicon } \\
\text { International, } \\
\text { Temecula, } \\
\text { USA }\end{array}$ & $\begin{array}{l}\text { rabbit } \\
\text { polyclonal }\end{array}$ & $1: 1500$ & $1: 400$ \\
\hline PACAP & $\begin{array}{l}\text { sc-25439, Santa Cruz } \\
\text { Biotechnology, Inc }\end{array}$ & $\begin{array}{l}\text { rabbit } \\
\text { polyclonal }\end{array}$ & $1: 300$ & $1: 400$ \\
\hline PAC1 & $\begin{array}{l}\text { sc-30018, Santa Cruz } \\
\text { Biotechnology, Inc }\end{array}$ & $\begin{array}{l}\text { rabbit } \\
\text { polyclonal }\end{array}$ & $1: 200$ & $1: 100$ \\
\hline GFAP & $\begin{array}{l}\text { Z0334, Dako, } \\
\text { Denmark }\end{array}$ & $\begin{array}{l}\text { rabbit } \\
\text { polyclonal }\end{array}$ & $1: 1500$ & $1: 400$ \\
\hline Iba-1 & $\begin{array}{l}\text { 019-19741 Wako } \\
\text { Chemicals USA }\end{array}$ & $\begin{array}{l}\text { rabbit } \\
\text { polyclonal }\end{array}$ & $1: 1000$ & $1: 400$ \\
\hline
\end{tabular}




\section{References}

ABBOTT, L. C. \& WINZER-SERHAN, U. H. 2012. Smoking during pregnancy: lessons learned from epidemiological studies and experimental studies using animal models. Crit Rev Toxicol, 42, 279-303.

ABDEL-RAHMAN, A., DECHKOVSKAIA, A. M., SUTTON, J. M., CHEN, W. C., GUAN, X., KHAN, W. A. \& ABOU-DONIA, M. B. 2005. Maternal exposure of rats to nicotine via infusion during gestation produces neurobehavioral deficits and elevated expression of glial fibrillary acidic protein in the cerebellum and CA1 subfield in the offspring at puberty. Toxicology, 209, 245-61.

AISHAH, A., HINTON, T., WATERS, K. A. \& MACHAALANI, R. 2019. The alpha3 and alpha4 nicotinic acetylcholine receptor (nAChR) subunits in the brainstem medulla of sudden infant death syndrome (SIDS). Neurobiol Dis, 125, 23-30.

BENGTSSON, F. \& HESSLOW, G. 2006. Cerebellar control of the inferior olive. Cerebellum, 5, 7-14.

BENOWITZ, N. L., BERNERT, J. T., CARABALLO, R. S., HOLIDAY, D. B. \& WANG, J. 2009. Optimal serum cotinine levels for distinguishing cigarette smokers and nonsmokers within different racial/ethnic groups in the United States between 1999 and 2004. Am J Epidemiol, 169, 236-48.

BERNSTEIN, I. M., MONGEON, J. A., BADGER, G. J., SOLOMON, L., HEIL, S. H. \& HIGGINS, S. T. 2005. Maternal smoking and its association with birth weight. Obstet Gynecol, 106, 986-91.

BOONE, T. B. \& ALDES, L. 1984. The ultrastructure of two distinct neuron populations in the hypoglossal nucleus of the rat. Experimental brain research, 54, 321-326.

BRODY, A. L., HUBERT, R., ENOKI, R., GARCIA, L. Y., MAMOUN, M. S., OKITA, K., LONDON, E. D., NURMI, E. L., SEAMAN, L. C. \& MANDELKERN, M. A. 2017. Effect of Cigarette Smoking on a Marker for Neuroinflammation: A [(11)C]DAA1 106 Positron Emission Tomography Study. Neuropsychopharmacology, 42, 1630-1639.

CHAN, Y. L., SAAD, S., AL-ODAT, I., ZAKY, A. A., OLIVER, B., POLLOCK, C., LI, W., JONES, N. M. \& CHEN, H. 2016a. Impact of maternal cigarette smoke exposure on brain and kidney health outcomes in female offspring. Clin Exp Pharmacol Physiol, 43, 1168-1176.

CHAN, Y. L., SAAD, S., POLLOCK, C., OLIVER, B., AL-ODAT, I., ZAKY, A. A., JONES, N. \& CHEN, H. 2016b. Impact of maternal cigarette smoke exposure on brain inflammation and oxidative stress in male mice offspring. Sci Rep, 6, 25881.

CHANG, G. Q., KARATAYEV, O. \& LEIBOWITZ, S. F. 2013. Prenatal exposure to nicotine stimulates neurogenesis of orexigenic peptide-expressing neurons in hypothalamus and amygdala. Journal of Neuroscience, 33, 13600-11.

CHANG, R. C., HO, Y. S., WONG, S., GENTLEMAN, S. M. \& NG, H. K. 2014. Neuropathology of cigarette smoking. Acta Neuropathol, 127, 53-69. 
DAMPNEY, R. A. 1994. Functional organization of central pathways regulating the cardiovascular system. Physiol Rev, 74, 323-64.

DICKSON, L. \& FINLAYSON, K. 2009. VPAC and PAC receptors: From ligands to function. Pharmacol Ther, 121, 294-316.

DIFRANZA, J.R., ALIGNE, C.A. \& WEITZMAN, M. 2004. Prenatal and postnatal environmental tobacco smoke exposure and children's health. Pediatrics,113,1007-15.

FANTUZZI, G., VACCARO, V., AGGAZZOTTI, G., RIGHI, E., KANITZ, S., BARBONE, F., SANSEBASTIANO, G., BATTAGLIA, M. A., LEONI, V., FABIANI, L., TRIASSI, M., SCIACCA, S. \& FACCHINETTI, F. 2008. Exposure to active and passive smoking during pregnancy and severe small for gestational age at term. $J$ Matern Fetal Neonatal Med, 21, 643-7.

FARNHAM, M. M. \& PILOWSKY, P. M. 2010. The role of PACAP in central cardiorespiratory regulation. Respir Physiol Neurobiol, 174, 65-75.

GHOSH, D., MISHRA, M. K., DAS, S., KAUSHIK, D. K. \& BASU, A. 2009. Tobacco carcinogen induces microglial activation and subsequent neuronal damage. $J$ Neurochem, 110, 1070-81.

GILLILAND, F. D., LI, Y. F. \& PETERS, J. M. 2001. Effects of maternal smoking during pregnancy and environmental tobacco smoke on asthma and wheezing in children. Am J Respir Crit Care Med, 163, 429-36.

GREEN, C.R. and RODGMAN, A., 1996. The Tobacco Chemists' Research Conference: a half century forum for advances in analytical methodology of tobacco and its products. Recent Adv Tobacco Sci, 22,131-304.

HAWKINS, J. L., DENSON, J. E., MILEY, D. R. \& DURHAM, P. L. 2015. Nicotine stimulates expression of proteins implicated in peripheral and central sensitization. Neuroscience, 290, 115-25.

HOFFMAN, H. J., DAMUS, K., HILLMAN, L. \& KRONGRAD, E. 1988. Risk factors for SIDS. Results of the National Institute of Child Health and Human Development SIDS Cooperative Epidemiological Study. Ann N Y Acad Sci, 533, 13-30.

HUANG, J., WATERS, K. A. \& MACHAALANI, R. 2017a. Pituitary adenylate cyclase activating polypeptide (PACAP) and its receptor 1 (PAC1) in the human infant brain and changes in the Sudden Infant Death Syndrome (SIDS). Neurobiol Dis, 103, 70-77.

HUANG, J., WATERS, K. A. \& MACHAALANI, R. 2017b. Hypoxia and nicotine effects on Pituitary adenylate cyclase activating polypeptide (PACAP) and its receptor 1 (PAC1) in the developing piglet brainstem. Neurotoxicology, 62, 30-38.

JAMEN, F., BOUSCHET, T., LADEN, J. C., BOCKAERT, J. \& BRABET, P. 2002. Upregulation of the PACAP type-1 receptor (PAC1) promoter by neurotrophins in rat PC12 cells and mouse cerebellar granule cells via the Ras/mitogen-activated protein kinase cascade. J Neurochem, 82, 1199-207. 
KADOYAMA, K., FUNAKOSHI, H., OHYA, W. \& NAKAMURA, T. 2007. Hepatocyte growth factor (HGF) attenuates gliosis and motoneuronal degeneration in the brainstem motor nuclei of a transgenic mouse model of ALS. Neurosci Res, 59, 44656.

LAU, W. K., MAK, J. C., CHAN, K. H. \& LAW, A. C. 2012. Cigarette smoke-induced cerebral cortical interleukin-6 elevation is not mediated through oxidative stress. Neurotox Res, 22, 170-6.

LIBERMAN, A. C., TRIAS, E., DA SILVA CHAGAS, L., TRINDADE, P., DOS SANTOS PEREIRA, M., REFOJO, D., HEDIN-PEREIRA, C. \& SERFATY, C. A. 2018. Neuroimmune and Inflammatory Signals in Complex Disorders of the Central Nervous System. Neuroimmunomodulation, 1-25.

LIU, Q. \& WONG-RILEY, M. T. 2013. Postnatal development of brain-derived neurotrophic factor (BDNF) and tyrosine protein kinase $\mathrm{B}(\mathrm{TrkB})$ receptor immunoreactivity in multiple brain stem respiratory-related nuclei of the rat. J Comp Neurol, 521, 109-29.

LIU, Q. \& WONG-RILEY, M. T. T. 2019. Pituitary adenylate cyclase-activating polypeptide: Postnatal development in multiple brain stem respiratory-related nuclei in the rat. Respir Physiol Neurobiol, 259, 149-155.

LUCK, W. \& NAU, H. 1985. Nicotine and cotinine concentrations in serum and urine of infants exposed via passive smoking or milk from smoking mothers. J Pediatr, 107, 816-20.

MACHAALANI, R. \& CHEN, H. 2018. Brain derived neurotrophic factor (BDNF), its tyrosine kinase receptor B (TrkB) and nicotine. Neurotoxicology, 65, 186-195.

MACHAALANI, R., RODRIGUEZ, M. \& WATERS, K. A. 2007. Active caspase-3 in the sudden infant death syndrome (SIDS) brainstem. Acta Neuropathol, 113, 577-84.

MACHAALANI, R., SAY, M. \& WATERS, K. A. 2011. Effects of cigarette smoke exposure on nicotinic acetylcholine receptor subunits alpha7 and beta2 in the sudden infant death syndrome (SIDS) brainstem. Toxicol Appl Pharmacol, 257, 396-404.

MACHAALANI, R. \& WATERS, K. A. 2008. Neuronal cell death in the Sudden Infant Death Syndrome brainstem and associations with risk factors. Brain, 131, 218-28.

MARGIOTTA, J. F. \& PARDI, D. 1995. Pituitary adenylate cyclase-activating polypeptide type I receptors mediate cyclic AMP-dependent enhancement of neuronal acetylcholine sensitivity. Mol Pharmacol, 48, 63-71.

PARDI, D. \& MARGIOTTA, J. F. 1999. Pituitary adenylate cyclase-activating polypeptide activates a phospholipase $\mathrm{C}$-dependent signal pathway in chick ciliary ganglion neurons that selectively inhibits alpha7-containing nicotinic receptors. J Neurosci, 19, 6327-37.

PARK, H. J., LEE, P. H., AHN, Y. W., CHOI, Y. J., LEE, G., LEE, D. Y., CHUNG, E. S. \& JIN, B. K. 2007. Neuroprotective effect of nicotine on dopaminergic neurons by antiinflammatory action. European Journal of Neuroscience, 26, 79-89. 
PAXINOS, G. and FRANKLIN, K.B., 2004. The mouse brain in stereotaxic coordinates. Gulf professional publishing.

REICHENSTEIN, M., REHAVI, M. \& PINHASOV, A. 2008. Involvement of pituitary adenylate cyclase activating polypeptide (PACAP) and its receptors in the mechanism of antidepressant action. $J$ Mol Neurosci, 36, 330-8.

SOVIK, S., LOSSIUS, K. \& WALLOE, L. 2001. Heart rate response to transient chemoreceptor stimulation in term infants is modified by exposure to maternal smoking. Pediatr Res, 49, 558-65.

TANG, S., MACHAALANI, R. \& WATERS, K. A. 2008. Brain-derived neurotrophic factor (BDNF) and TrkB in the piglet brainstem after post-natal nicotine and intermittent hypercapnic hypoxia. Brain Res, 1232, 195-205.

TANG, S., MACHAALANI, R. \& WATERS, K. A. 2010. Immunolocalization of pro- and mature-brain derived neurotrophic factor (BDNF) and receptor TrkB in the human brainstem and hippocampus. Brain Res, 1354, 1-14.

TANG, S., MACHAALANI, R. \& WATERS, K. A. 2012. Expression of brain-derived neurotrophic factor and TrkB receptor in the sudden infant death syndrome brainstem. Respir Physiol Neurobiol, 180, 25-33.

VAUDRY, D., GONZALEZ, B. J., BASILLE, M., YON, L., FOURNIER, A. \& VAUDRY, H. 2000. Pituitary adenylate cyclase-activating polypeptide and its receptors: from structure to functions. Pharmacol Rev, 52, 269-324.

VIVEKANANDARAJAH, A., CHAN, Y. L., CHEN, H. \& MACHAALANI, R. 2016. Prenatal cigarette smoke exposure effects on apoptotic and nicotinic acetylcholine receptor expression in the infant mouse brainstem. Neurotoxicology, 53, 53-63.

VIVEKANANDARAJAH, A., WATERS, K. A. \& MACHAALANI, R. 2019. Cigarette smoke exposure effects on the brainstem expression of nicotinic acetylcholine receptors (nAChRs), and on cardiac, respiratory and sleep physiologies. Respir Physiol Neurobiol, 259, 1-15.

WISBORG, K., KESMODEL, U., HENRIKSEN, T. B., OLSEN, S. F. \& SECHER, N. J. 2001. Exposure to tobacco smoke in utero and the risk of stillbirth and death in the first year of life. Am J Epidemiol, 154, 322-7.

YOUNES-RAPOZO, V., MOURA, E. G., MANHAES, A. C., PINHEIRO, C. R., CARVALHO, J. C., BARRADAS, P. C., DE OLIVEIRA, E. \& LISBOA, P. C. 2015. Neonatal Nicotine Exposure Leads to Hypothalamic Gliosis in Adult Overweight Rats. Journal of Neuroendocrinology, 27, 887-98.

ZELIKOFF, J. T., PARMALEE, N. L., CORBETT, K., GORDON, T., KLEIN, C. B. \& ASCHNER, M. 2018. Microglia Activation and Gene Expression Alteration of Neurotrophins in the Hippocampus Following Early-Life Exposure to E-Cigarette Aerosols in a Murine Model. Toxicol Sci, 162, 276-286.

ZINK, M., OTTO, C., ZORNER, B., ZACHER, C., SCHUTZ, G., HENN, F. A. \& GASS, P. 2004. Reduced expression of brain-derived neurotrophic factor in mice deficient for 
pituitary adenylate cyclase activating polypeptide type-I-receptor. Neurosci Lett, 360, 106-8. 